\title{
MENINGKATKAN HASIL BELAJAR MATEMATIKA MELALUI PENERAPAN METODE KERJA KELOMPOK DENGAN BANTUAN TUTOR SEBAYA PADA SISWA KELAS VIII SMP NEGERI 1 DONGGO TAHUN PELAJARAN 2013-2014
}

\author{
Oleh: Andang
}

\begin{abstract}
Abstrak: Hasil penelitian ini menunjukkan bahwa: (1). Tingkat penguasaan materi ajar siswa Kelas VIII SMP Negeri 1 Donggo sebelum pelaksanaan sikius I memperoleh nilai rata-rata 61,40 dengan kategori sedang, setelah dilaksanakan tindakan pada sikius I siswa memperoleh nilai rata-rata 70,325\% dengan kategori tinggi dan pada sikius II memperoleh nilai rata-rata 75,925 dengan kategori tinggi dan (2). Tingkat kemajuan asi1 belajar siswa sebelum dilaksanakan tindakan pada sikius I dan setelah dilaksanakan tindakan pada sikius I sampai pada sikius II mengalami peningkatan. Ini menandakan bahwa ada peningkatan hasil belajar siswa Kelas VIII SMP Negeri 1 Donggo melalui pembelajaran metode kerja kelompok dengan bantuan tutor sebaya. Hasil dari pelaksanaan penelitian tindakan kelas ini akan memberikan manfaat yang berarti bagi perorangan/instansi sebagai berikut: (1). Bagi guru: hasil penelitian ini, menjadi masukan bagi para guru untuk dapat mengetahui strategi pembelajaran yang bervariasi yang dapat memperbaiki dan meningkatkan sistem pembelajaran di kelas, khususnya mata pelajaran Bahasa Indonesia dan guru mata pelajaran lain pada umumnya. (2). Bagi siswa: Hasil penelitian ini sangat bermanfaat bagi siswa yang bermasalah di kelas terutama siswa yang memiliki kemampuan kurang, minat dan motivasi yang rendah dalam belajar. (3). Bagi sekolah: Hasil penelitian ini memberikan sumbangan yang sangat berarti bagi sekolah dalam rangka perbaikan pembelajaran khususnya dan sekolah pada umumnya.
\end{abstract}

Kata Kunci; Metode kerja kelompok, Tutor sebaya dan hasil belajar

\section{Pendahuluan}

Penelitian ini dimaksudkan untuk memecahkan masalah rendahnya hasil belajar siswa Kelas VIII SMP Negeri 1 Donggo, Hal ini dapat dilihat dari rendahnya daya serap pada setiap semester yang diperoleh siswa pada Tahun Pelajaran 2012/2013 rata-ratanya hanya 62,15 ini tergolong kategori sedang bila dibandingkan dengan mata pelajaran lain. Berdasarkan studi pendahuluan yang lakukan peneliti,ini terjadi disebabkan oleh beberapa faktor, baik yang berasal dari dalam siswa itu sendiri maupun dan luar siswa. Banyak siswa yang tidak hanya kurang mampu memahami konsep konsep dan pemahaman yang diajarkan oleh guru. Ini disebabkan kebanyakan siswa menganggap bahwa pelajaran matematika merupakan pelajaran yang cukup sulit. Di dalam dunia pendidikan, diperlukan suatu usaha dalam pencapaian tujuan pengajaran 
melalui proses belajar mengajar yang efektif dan efisien, hal ini sejalan dengan yang diungkapkan oleh Winarno Surakhmad (1994: 14) bahwa:

"pendidikan disempitkan dalam pengertian pengajaran adalah suatu usaha yang bersifat sadar, tujuan yang sistematik terarah pada perubahan tingkah laku menuju kedewasaan anak didik. Perubahan yang dimaksud itu menunjuk pada suatu proses yang akan dilalui. Tanpa proses itu, tujuan tidak dapat dicapai dan proses yang dimaksudkan di sini adalah proses pendidikan atau proses edukatif."

Selaku guru mata pelajaran melihat proses belajar mengajar pelajaran matematika di kelas ternyata kemampuan siswa dalam menyelesaikan soal-soal atau tugas yang diberikan guru, baik berupa soal latihan, soal tugas pekerjaan rumah ataupun soal ulangan harian, sebagian besar belum dapat diselesaikan dengan baik, hal ini dapat terlihat pada waktu kegiatan pembelajaran di dalam kelas, masih banyak siswa yang tidak aktif menyelesaikan atau mengerjakan soal-soal atau tugas yang diberikan oleh guru, namun menunggu di papan tulis ada penyelesaian barulah aktif menulis. Disamping itu, hal-hal yang mengganggu dalam menyajikan materi di depan kelas, adalah banyak siswa yang lambat dalam menerima materi, tetapi ada beberapa siswa yang agak cepat menerima materi yang diberikan sehingga membuat materi dijelaskan berulang-ulang. Namun demikian pada saat siswa rnengerjakan soal-soal ataupun tugas masih banyak pula yang belum dapat diselesaikan dengan baik.

Berdasarkan uraian di atas, maka kami sebagai guru disekolah tertarik untuk mengadakan penelitian tentang penggunaan metode kerja kelompok dengan bantuan tutor sebaya dalam menyelesaikan soal-soal atau tugas dalam proses helajar mengajar dengan harapan siswa yang memiliki kemampuan kurang dalam belajar baik berupa pengetahuan, sikap dan tingkah laku dapat termotivasi untuk memperoleh kemampuan yang lebih baik.

Berdasarkan fenomena diatas maka hipotesis yang diajukan dalam penelitian ini, adalah jika guru menerapkan metode kerja kelompok dengan bantuan tutor sebaya, maka diduga bahwa kemampuan siswa dalam menyelesaikan soal-soal ulangan atau tugas yang diberikan guru dapat dimotivasi dan rendahnya hasil belajar siswa dapat ditingkatkan.

\section{Metode Penelitian}

Penelitian ini merupakan penelitian tindakan kelas (Classrom Action Research) yang melibatkan refleksi yang berulang, yaitu: perencanaan, tindakan, observasi, refleksi, perencanaan ulang dan seterusnya. Subjek penelitian ini adalah siswa Kelas VIII SMP Negeri 1 Donggo tahun pelajaran 2013-2014, yang berjumlah 40 orang siswa, terdiri dari 14 orang laki-laki dan 26 orang siswa perempuan. 
Adapun perencanaan dalam penelitian ini dirancang dalam dua siklus kegiatan yaitu: (1). siklus pertama dirancang dilakukan selam tiga kali perternuan. (2).siklus kedua dirancang dilakukan selama tiga kali pertemuan

Siklus I: Siklus pertama berlangsung selama 3 kali pertemuan atau 6 × 45 menit. Standar kompetensi / kompetensi dasar pada siklus I sebagai berikut:

Tahap Perencanaan; (a). Menelaah kurikulum berbasis kompetensi (KBK) Kelas VIII mata pelajaran matematika. (b). Membuat rencana pelaksanaan pembelajaran. (c). Membuat pedoman observasi untuk merekam kegiatan siswa dalam proses pembelajaran dsikusi kelas. (d). Membuat alat evaluasi untuk melihat kemampuan siswa dalam menyelesaikan soal-soal.

Tahap Pelaksanaan Tindakan; (a). Membagi siswa ke dalam beberapa kelompok, yang terdiri dan 4-6 orang siswa termasuk yang ditunjuk sebagai tutor sebaya untuk membantu teman-temannya. (b). Guru memberikan motivasi kepada siswa, dan memberikan informasi tentang kompetensi dasar. (c). Guru bersama siswa membahas materi dan memberi contoh secara klasikal. (d). Guru memberi kesempatan kepada siswa untuk bertanya, apabila masih ada yang kurang jelas. (e). Siswa bergabung pada kelompok untuk mengerjakan soal latihan atau soal yang diberikan guru. (f). Guru membimbing sambil mengamati siswa dalam kelompoknya. (g). Guru memberikan respon terhadap perilaku siswa dalam mengikuti kegiatan pembelajaran baik dalam menerima materi maupun dalam kelompok: misalnya memberikan teguran untuk memperhatikan, maupun dalam bekerja sama dengan teman-temannya. (h). Guru menunjuk beberapa siswa untuk mengerjakan soal.

Tahap Observasi dan Evaluasi; Pada tahap ini penulis dibantu teman sejawat,untuk; (a). Mengamati setiap kegiatan siswa melalui lembar observasi.(b). Mencatat beberapa kejadian yang dianggap penting.(c). Pada akhir siklus pertama ini diberikan tes untuk melihat kemampuan siswa dalam menyelesaikan soal-soal.(d) Melaksanakan evaluasi terhadap data yang telah diperoleh

Tahap Refleksi; Tahap ini peneliti dan observer mendiskusikan(menganalisis) kembali hasil yang diperoleh pada tahap observasi dan evaluasi,apakah kegiatan yang dilaksanakan telah dapat meningkatkan kemampuan siswa dalam menyelesaikan soal-soal. Hasil analisis data yang dilaksanakan dalam tahap ini akan digunakan sebagai acuan untuk melaksanakan tindakan pada siklus berikutnya.

Siklus II; Siklus kedua berlangsung selama 3 kali pertemuan atau $6 \times 45$ menit. Langkah-langkah kegiatan yang dilakukan pada siklus kedua pada umumnya merupakan pengulangan kegiatan yang dilakukan pada siklus pertama. Namun diadakan beberapa perubahan antara lain(a). Merumuskan tindakan selanjutnya berdasarkan hasil refleksi dan siklus I.(b). Melaksanakan tindakan 
siklus II.(c). Pada akhir siklus kedua diberikan tes untuk melihat kemampuan siswa dalam menyelesaikan soal-soal.(d). Menganalisis hasil tes dan hasil pengamatan pada siklus II.(d). Setelah diadakan siklus kedua diharapkan hasilnya lebih baik

Pengumpulan data adalah prosedur yang sistimatis dan standar untuk memperoleh data yang diperlukan (Nazir,1988;211). Penulis dalam penelitian ini menggunakan beberapa tekhnik dalam pengumpulan data.Adapun data dan pengumpulannya adalah (a). Sumber data: sumber data penelitian ini siswa dan metode pembelajaran yang digunakan. (b). jenis data: jenis data yang diperoleh dan sumber data adalah data kuantitatif yang berupa hasil tes dan data kualitatif berupa rekaman pengamatan selama proses pembelajaran dan tanggapan siswa. (c). Analisis data: data yang diperoleh dan hasil penelitian selanjutnya dianalisis secara deskriptif dengan cara rata-rata kelas.

Data yang terkumpul dalam penelitian ini dianalisis dengan teknik kualitatif dan kuantitatif. Untuk analisis secara kuantitatif digunakan statistik deskriptif, untuk mendeskriptiflcan karakteristik dari subjek penelitian, sedangkan untuk analisis data secara kualitatif digunakan dengan cara pengelompokan berdasarkan data kualitatif.

\section{Hasil Dan Pembahasan}

Berdasarkan hasil refleksi dari berbagai sumber data yang dikumpulkan penulis diketahui ,hasil analisis menunjukkan adanya perubahan positif peningkatan kemampuan menyelesaikan soal-soal matematika melalui metode kerja kelompok dengan bantuan tutor sebaya Siswa Kelas VIII SMP Negeri 1 Donggo, yang diukur dan hasil belajar matematika melalui tes. Adapun yang dianalisis adalah hasil tes awal sebelum pelaksanaan tindakan, hasil tes akhir siklus I dan siklus II. Secara rinci perbandingan hasil penelitian ini adalah sebagai berikut:

\section{Sebelum pelaksanaan tindakan}

Dari analisis statistik deskriptif (lihat Lampiran 9) terhadap nilai tes awal sebelum pemberian tindakan melalui metode kerja kelompok dengan bantuan tutor sebaya di sajikan pada tabel berikut ini.

\begin{tabular}{|c|c|}
\hline Stastik & Nilai Statistik \\
\hline Subyek & 40 \\
\hline Nilai Tertinggi & 82 \\
\hline Nilai terendah & 45 \\
\hline Rentang Nilai & 37 \\
\hline Rata rata & 61,400 \\
\hline Standar deviasi & 10,279 \\
\hline
\end{tabular}


Tabel 4.1.2 menunjukkan bahwa terdapat 0 siswa atau $0.00 \%$ yang memiliki hasil belajar matematika sebelum pelaksanaan tindakan melalui metode kerja kelompok dengan bantuan tutor sebaya berada pada kategori sangat rendah, 11 siswa atau 27,50\% berada pada kategori rendah, 17 siswa atau 42,50\% berada pada kategori sedang, 12 siswa atau 30,00\% berada pada kategori tinggi dan 0 siswa atau $0,00 \%$ berada pada kategori sangat tinggi. Jika nilai rata-rata hasil belajar matematika siswa sebelum pelaksanaan tindakan melalui metode kerja kelompok dengan bantuan tutor sebaya yakni 61,400 yang dihubungkan dalam tabel kategori di atas, maka nilai rata-rata hasil belajar matematika siswa berada dalam kategori sedang.

Hasil belajar Matematika setelah pelaksanaan tindakan Siklus I

Dan analisis statistik deskriptif terhadap nilai tes Siklus I setelah pemberian tindakan melalui metode kerja kelompok dengan bantuan tutor sebaya di sajikan pada tabel berikut ini.

Tabel 4.3. Statistik Hasil Belajar Siswa Setelah Pelaksanaan Tindakan

\begin{tabular}{|c|c|}
\hline Stastik & Nilai Statistik \\
\hline Subyek & 40 \\
\hline Nilai Tertinggi & 95 \\
\hline Nilai terendah & 55 \\
\hline Rentang Nilai & 40 \\
\hline Rata rata & 70,325 \\
\hline Standar deviasi & 9,679 \\
\hline
\end{tabular}

Tabel 4.3 di atas menunjukkan bahwa nilai rata-rata hasil belajar matematika siswa setelah pelaksanaan tindakan Siklus I melalui metode kerja kelompok dengan bantuan tutor sebaya adalah 70,325, dan nilai tertinggi 95 sedangkan nilai terendah adalah 55 dengan standar deviasi adalah 9.679.

Jika nilai hasil belajar matematika siswa setelah pelaksanaan tindakan Siklus I melalui metode kerja kelompok dengan bantuan tutor sebaya dikelompokkan kedalam lima kategori, seperti yang telah dijelaskan pada Bab III bagian teknik analisis data. Dengan memodifikasi pengkategorian tersebut maka diperoleh distribusi frekuensi dan persentase nilai seperti ditunjukkan pada tabel berikut:

Tabel 4.4 Distribusi Frekuensi dan Persentase Nilai Hasil Belajar matematika Siswa Setelah Pelaksanaan Tindakan Siklus I

\begin{tabular}{|c|c|c|c|}
\hline Nilai & Kategori & Frekuensi & Presentase \\
\hline $0-34$ & Sangat Rendah & 0 & 0,000 \\
\hline $35-54$ & Rendah & 11 & 27,50 \\
\hline $55-64$ & Sedang & 1712 & 42,50 \\
\hline $65-84$ & Tinggi & 12 & 30,00 \\
\hline $85-100$ & Sangat Tinggi & 0 & 0,000 \\
\hline \multicolumn{4}{|l}{} \\
\hline
\end{tabular}


Tabel 4.4 menunjukkan bahwa terdapat 0 siswa atau 0,00\% yang memiliki hasil belajar matematika setelah pelaksanaan tindakan Siklus I melalui metode kerja kelompok dengan bantuan tutor sebaya berada pada kategori sangat rendah maupun rendah, 11 siswa atau $27,50 \%$ berada pada kategori sedang, 25 siswa atau $62.50 \%$ berada pada kategori tinggi dan 4 siswa atau 10,00\% berada pada kategori sangat tinggi. Jika nilai rata-rata hasil belajar Bahasa Indonesia siswa setelah pelaksanaan tindakan Siklus 1 melalui metode kerja kelompok dengan bantuan tutor sebaya yakni 70,325 yang dihubungkan dalam tabel kategori di atas, maka nilai rata-rata hasil belajar matematika siswa berada dalam kategori tinggi.

Hasil belajar Matematika setelah pelaksanaan tindakan Siklus II

Dari analisis statistik deskriptif terhadap nilai tes Siklus II setelah pemberian tindakan melalui metode kerja kelompok dengan bantuan tutor sebaya di sajikan pada tabel berikut ini.

Tabel 4.5 Statistik Hasil Belajar Siswa Setelah Pelaksanaan Tindakan Siklus II Melalui Metode Kerja Kelompok dengan Bantuan Tutor Sebaya

\begin{tabular}{|c|c|}
\hline Stastik & Nilai Statistik \\
\hline Subyek & 40 \\
\hline Nilai Tertinggi & 98 \\
\hline Nilai terendah & 62 \\
\hline Rentang Nilai & 36 \\
\hline Rata rata & 75,925 \\
\hline Standar deviasi & 9,395 \\
\hline
\end{tabular}

Tabel 4.5 di atas menunjukkan bahwa nilai rata-rata hasil belajar matematika siswa setelah pelaksanaan tindakan Siklus II melalui metode kerja kelompok dengan bantuan tutor sebaya adalah 75,925 dan nilai tertinggi 98 sedang nilai terendah adalah 62 dengan standar deviasi adalah 9,395

Jika nilai hasil belajar matematika siswa setelah pelaksanaan tindakan Siklus II melalui metode kerja kelompok dengan bantuan tutor sebaya dikelompokkan kedalam lima kategori, seperti yang telah dijelaskan pada Bab III bagian teknik analisis data. Dengan memodifikasi pengkategorian tersebut maka diperoleh distribusi frekuensi dan persentase nilai seperti ditunjukkan pada tabel berikut:

Tabel 4.6 Distribusi Frekuensi dan Persentase Nilai Hasil Belajar

\begin{tabular}{|c|c|c|c|}
\hline Nilai & Kategori & Frekuensi & Presenatase \\
\hline $0-34$ & Sangat Rendah & 0 & 0,00 \\
\hline $35-54$ & Rendah & 0 & 0,00 \\
\hline $55-64$ & Sedang & 1 & 2,50 \\
\hline $65-84$ & Tinggi & 31 & 77,50 \\
\hline $85-100$ & Sgt Ting & 8 & 20,00 \\
\hline \multicolumn{2}{|c|}{ Jumlah } & 40 & $100 \%$ \\
\hline
\end{tabular}


Tabel 4.6 menunjukkan bahwa terdapat 0 siswa atau 0,00\% yang memiliki hasil belajar matematika setelah pelaksanaan tindakan Siklus II melalui metode kerja kelompok dengan bantuan tutor sebaya berada pada kategori sangat rendah maupun rendah, 1 siswa atau $2,50 \%$ berada pada kategori sedang, 31 siswa atau $77,50 \%$ berada pada kategori tinggi, dan 8 siswa yang berada pada kategori sangat tinggi.Jika nilai rata-rata hasil belajar matematika siswa seteläh pelaksanaan tindakan Siklus II melalui metode kerja kelompok dengan bantuan tutor sebaya yakni 75,925 yang dihubungkan dalam tabel kategori di atas, maka nilai rata-rata hasil belajar matematika siswa berada dalam kategori tinggi.

\section{Perubahan Sikap Siswa Siklus I}

Dari awal penelitian berlangsung hingga berakhirnya Siklus I tercatat beberapa perubahan yang terjadi pada siswa seperti:

1. Perhatian siswa terhadap proses belajar mengajar sudah terlihat meningkat meskipun belum maksimal. Kemauan dan keseriusan nampak sekali terlihat pada tutor masing-masing kelompok untuk senantiasa mengetahui materi yang diajarkan dengan mengajukan pertanyaan tentang materi yang belum dimengerti. Namun pada pertemuan ketiga sampai selesai siklus, siswa terlihat aktif dibanding pertemuan pertama dan kedua. Siswa sudah ada dan anggota masing-masing kelompok yang sering mengajukan pertanyaan pada setiap pertemuan.

2. Keberanian siswa bertanya dan menjawab soal yang diberikan juga meningkat. Hal ini terlihat dengan adanya beberapa siswa yang ingin mengerjakan soal-soal yang diberikan oleh guru.

3. Jumlah siswa yang mengerjakan soal-soal yang diberikan masih kurang atau sekitar rata-rata 7 orang setiap pertemuan

4. Kerja sama pada setiap kelompok masih kurang sehingga perlu bimbingan oleh tutor sebaya atau guru

\section{Siklus II}

Pada saat berlangsungnya Siklus II beberapa perubahan yang terjadi pada diri siswa antara lain:

1. Perhatian siswa terhadap proses belajar mengajar semakin meningkat. Hal ini dapat dilihat dari setiap kelompok sangat aktif dalam mengikuti proses-proses dari setiap pengembangan konsep dan kehadiran siswa pada siklus ini 100\% dari 4 kali pertemuan.

2. Kemauan siswa dalam menjawab soal yang diberikan juga meningkat. hal ini terlihat banyak siswa yang mampu mengerjakan soal-soal latihan dengan benar pada setiap pertemuan.

3. Semangat siswa untuk mengerjakan soal yang diberikan juga meningkat. hal ini terlihat pada pemberian soal latihan siswa 
pada setiap kelompok tidak ragu-ragu lagi mengerjakan soal yang diberikan oleh guru.

4. Kerja sama dari masing-masing anggota kelompok sangat aktif dan banyaknya pertanyaan yang diajukan siswa baik kepada tutornya maupun kepada peneliti berkisar antara 10 - 15 orang pada tiap pertemuan dalam siklus ini. hal ini juga terlihat tidak ada siswa yang meninggalkan kelas atau bermain saat pembelajaran berlangsung.

\section{Refleksi Terhadap Pelaksanaan Proses Belajar Mengajar \\ Siklus I \\ Refleksi terhadap kelompok belajar}

Pada pekan awal pelaksanaan Siklus I, semangat dan keaktifan siswa dalam mengikuti proses belajar mengajar masih kurang. Hal ini mungkin disebabkan karena pada Siklus I, kelompok belajar dalam kelas dibagi menjadi 4 kelompok dengan masing-masing 6 sampai 7 orang. Pembagian kelompok dengan jumlah anggota yang banyak terlihat tidak efektif sebab tutor tidak mampu mengatasi kesulitan yang dialami anggota kelompoknya mengenai materi yang telah diajarkan sehingga semangat belajar hanya terlihat pada siswa yang memang sudah mempunyai semangat belajar sebelum penelitian ini dilaksanakan.

Refleksi terhadap proses belajar mengajar

Semangat dan perhatian siswa untuk mengikuti proses pembelajaran pada Siklus I masih rendah, hal ini terlihat bahwa masih banyaknya siswa yang tidak memperhatikan pembahasan materi pembelajaran. Dan siswa yang dapat menjawab pertanyaan yang diajukan peneliti pada saat pengembangan pemahaman konsep masih kurang atau hanya berkisar antara 3 sampai 4 orang setiap pertemuan dan banyaknya siswa yang mampu menjawab soal dengan benar pada penerapan konsep serta siswa yang mau menyelesaikan soal-soal pada papan tulis hanya berkisar 3 sampai 6 orang pada tiap pertemuan.

Dari beberapa hal di atas dapat dikatakan bahwa interaksi belajar mengajar kurang nampak. Siswa yang aktif memberikan respon pertanyaan, komentar, dan tanggapan hanya siswa yang tergolong pintar atau siswa yang memperoleh nilai baik pada ulangan harian atau semester sebelum penelitian ini dilaksanakan.

\section{Siklus II}

Refleksi terhadap kelompok belajar

Berdasarkan hasil refleksi pada Siklus I, pada Siklus II ini kelompok belajar dibagi menjadi 5 kelompok dengan anggota masing-masing 5 orang dengan pembagian kelompok tersebut semangat siswa dalam mengikuti proses belajar mengajar sudah mulai meningkat. Hal ini dapat dilihat tutor pada tiap kelompok 
sudah mampu mengakomodasi kesulitan yang alami oleh anggotanya, dalam hal ini materi pelajaran yang telah diajarkan.

Dengan diubahnya kelompok belajar dengan memperkecil jumlah anggotanya siswa lebih bersemangat dalam belajar. $\mathrm{Hal}$ ini disebabkan karena anggota-anggota kelompok sudah merasa senang dan lebih akrab.

Refleksi terhadap proses belajar mengajar

Semangat siswa untuk mengikuti proses belajar mengajar pada siklus ini sudah meningkat. Hal ini dapat dilihat bahwa siswa yang memperhatikan pembahasan materi pelajaran sekitar $100 \%$ dan siswa yang dapat menjawab pertanyaan yang diajukan peneliti pada saat pengembangan konsep berkisar antara 8 sampai 14 orang tiap pertemuan. Dan banyak siswa yang mampu menjawab soal-soal dengan benar pada penerapan konsep, serta siswa yang mau menyelesaikan soal-soal pada papan tulis berkisar antara 10 sampai 20 orang setiap pertemuan.

Dari bebarapa hal di atas dapat dikatakan bahwa interaksi belajar mengajar pada Siklus II ini sangat meningkat, sebab siswa yang aktif memberi respon. pertanyaan dan tanggapan bukan hanya siswa yang tergolong pintar atau yang mempunyai nilai baik pada ulangan sebelumnya.

\section{Pembahasan Analisis Refleksi Siswa}

Dari analisis terhadap refleksi yang ditulis oleh siswa dapat dikemukakan sebagai berikut:

Pendapat siswa terhadap pelajaran Matematika

Umumnya siswa menganggap bahwa matematika adalah mata pelajaran yang banyak membaca serta penerapan dalam kehidupan sehari-hari, oleh karena itu mempelajari matematika sangat perlu dan harus dipelajari karena dengan memahami materi matematika maka pelajaran yang lain juga mudah dipahami.

Bagi siswa yang tergolong pintar menyatakan bahwa mereka senang mempelajari matematika karena dapat diamalkan dan dikembangkan utamanya dalam hidup bermasyarakat maupun di sekolah. Dan materinya banyak berhubungan dalam kehidupan sehari-hari.

Manfaat belajar kelompok dengan tutor sebaya

Tanggapan siswa dari awal hingga akhir penelitian tindakan ini menyatakan manfaat pembelajaran kelompok dengan tutor sebaya antara lain:

1. Pada pembelajaran kelompok dengan tutor sebaya dapat merangsang siswa berpikir secara demokratis berdasarkan konsep, prinsip yang telah diberikan.

2. Pada pembelajaran kelompok dengan tutor sebaya, siswa dapat lebih aktif dalam proses belajar mengajar sebab terjadi persaingan kelompok yang bertujuan untuk memajukan 
kelompoknya, yang pada akhirnya dapat menumbuhkan semangat belajar setiap siswa.

3. Pada pembelajaran kelompok dengan tutor sebaya, siswa yang tergolong mampu (pintar) membantu secara bertanggung jawab dalam membelajarkan teman-temannya yang kurang mampu (bodoh).

4. Pada pembelajaran kelompok dengan tutor sebaya, siswa yang kurang mampu (bodoh) dapat lebih mudah memperoleh informasi yang berkaitan dengan hal-hal yang belum dimengerti baik pada saat pembelajaran berlangsung maupun sesudah pembelajaran.

5. Pada pembelajaran kelompok dengan tutor sebaya, dapat meminimalkan kesalahan yang mungkin terjadi pada siswa dalam proses belajar mengajar.

Dengan demikian sebagai masukan dari siswa bahwa pada pembelajaran kelompok dengan tutor sebaya sangat memberi manfaat, sehingga metode ini merupakan salah satu metode pembelajaran yang dapat diterapkan pada pembelajaran di sekolah.

\section{Simpulan}

Setelah diadakan penelitian tindakan kelas ini, maka penulis dapat menyimpulkan hasil penelitian sebagai berikut:

1. Rata-rata hasil belajar matematika siswa sebelum penelitian tindakan kelas adalah 16,244 dan skor ideal yang mungkin dicapai yaitu 25, sedangkan rata-rata hasil belajar Bahasa Indonesia siswa setelah diadakan tindakan kelas melaui metode kerja kelompok dengan bantuan tutor sebaya dan dua siklus yaitu Siklus I adalah 27,089 dan siklus II adalah 30,60, dan skor ideal yang mungkin dicapai yaitu 40. Dari hasil tersebut diperoleh keterangan bahwa hasil belajar matematika dalam hal ini kemampuan menyelesaikan soal-soal Siswa Kelas VIII SMP Negeri 1 Donggo mengalami peningkatan.

2. Adanya peningkatan ketuntasan hasil belajar yakni sebelum diadakan tindakan (tes awal) 16 siswa $(35,56 \%)$ yang tuntas, setelah diadakan tindakan (Siklus I) 32 siswa (71,1 1\%) yang tuntas, dan Siklus II 40 siswa $(88,89 \%)$ yang tuntas. Dari hasil ini diperoleh keterangan bahwa Siklus II ini telah mencapai ketuntasan belajar secara klasikal sebagaimana yang telah ditetapkan oleh Depdiknas bahwa tuntas belajar secara klasikal jika telah mencapai $85 \%$ dari jumlah siswa yang telah memperoleh skor minimal $65 \%$ dan skor ideal.

3. Semangat dan tanggung jawab siswa dalam mengikuti proses belajar mengajar sangat tinggi. Dengan demikian siswa dapat menyelesaikan tugas yang diberikan baik tugas di sekolah maupun di rumah. 
4. Dengan belajar kelompok dengan tutor sebaya siswa dapat mengetahui letak kesalahan-kesalahan dalam menyelesaikan soal sebab dipantau langsung oleh tutor.

5. Hasil belajar Bahasa Indonesia siswa mengalami peningkatan melalui pembelajaran kelompok dengan tutor sebaya.

\section{Saran}

Dari hasil penelitian yang diperoleh, baik peningkatan hasil belajar matematika siswa maupun perubahan sikap positif siswa terhadap pelajaran matematika. maka diajukan saran sebagai berikut:

1. Diharapkan kepada guru matematika, agar menerapkan metode pembelajaran kelompok dengan tutor sebaya sebagai altematif untuk meningkatkan hasil belajar matematika.

2. Dalam menerapkan pembelajaran kelompok dengan bantuan tutor sebaya sebaiknya anggota kelompok tidak terlalu banyak, agar tutor dapat melayani kesulitan-kesilitan belajar yang dialami anggota kelompoknya.

3. Untuk meningkatkan hasil belajar siswa pada mata pelajaran yang diikutinya maka direkomendasikan agar guru bidang studi lainnya dapat menerapkan metode ini dengan perubahanperubahan yang sesuai.

\section{Daftar Pustaka}

Depdikbud,1993, Kurikulum lanjutan sekolah tingkat Pertama (SLTP) Petunjuk Proses belajar mengajar, Jakarta: Depdikbud

Depdikbud, 1994. Petunjuk Proses belajar mengajar, Jakarta Balai Pustaka

Djamarah, Dkk,1996, Strategi Belajar Mengajar, Jakarta Rineka Cipta

Henick Keck, 1995,Saya Gaya yang baik, Yogyakarta, Karisius

Hasibuan,JJ,JJ, dan Mudjono, 1995, Proses belajara mengajar, Bandung: Rehaja Rosdarya

Muhammad Jari Jang, 1994 Jurnal Ilmah Pendidikan Mipa, VolI Nomor I ujung Pandang FPMIPA IKIP Ujung Pandang

Nasution, S, 1986, Didaktik asas asas mengajar, Bandung: Jemmars

Poerwadarminto W.J.S, 1984 Kamus Besar Bahasa Indonesia, Jakarta: balai pustaka, Rostiyah NK, 1989, Masalah masalah Ilmu Keguruan, Jakarta Bumi Aksara. 